\title{
NATIONAL LEVEL LARGE-SCALE ASSESSMENT DATA FOR INSTRUCTIONAL PLANNING IN CLASSROOM
}

\author{
Pavels Pestovs \\ University of Latvia, Latvia \\ Dace Namsone \\ University of Latvia, Latvia
}

\begin{abstract}
Large scale assessments are used for many purposes, but for all purpose's teachers are rarely recognising the use of large-scale assessment for instructional planning. The feedback from large scale assessment very often is too abstract and of no use to the students, especially if the large-scale assessment is administrated in the end of term. Teachers primarily use their intuition to plan instructional decisions, however in time of vast different political initiatives, it is very important to introduce in school data-driven decision making.

Authors are working in the theoretical framework that assessment data in aligned and interconnected fashion with instruction is important in making high quality educational decisions and data should be interpreted in context to be transformed to the meaningful information. The study design is based on in-depth analysis of $6^{\text {th }}$ grade national level largescale assessment data in Science, Native language (Latvian language) and Mathematics and teacher performance data in classroom. In focus groups experts deconstructed the aggregated data from the large-scale assessment in several iterations and map items according to the theoretical constructs according to new curriculum reform. Data have been analysed according to the general framework of data-decision making. Authors have found, teacher performance data and deconstructed large-scale assessment data, organized in interconnected way between different subjects, of high use in data driven decision making process. The authors have piloted the model, in which deconstructed data were used to make decisions to improve student learning outcomes in classroom.
\end{abstract}

Keywords: large-scale assessment, data-driven decision making, data literacy.

\section{Introduction}

Employment distribution over the last years has shifted towards jobs with non-routine skills. High cognitive skills encompass problem-solving, abstract reasoning, and decision-making, but low cognitive skills demand basic human adaptability (Dorn, 2009). Therefore, education systems 
shift to the implementing and promoting higher order thinking skills in curriculum. Countries are trying to their best to improve the quality of education (Wiliam, 2018a). Similar process is observed in Latvia, where National Centre for Education has launched a comprehensive curriculum reform, prioritising $21^{\text {st }}$ century skills such as problem solving and critical thinking, collaboration, citizenship, creativity and entrepreneurship, digital literacy and self-regulated learning. The content of the curriculum has been organized in seven learning areas: languages, social sciences, cultural understanding and artistic self-expression, natural sciences, mathematics, technology, and health and physical activity with complex learning outcomes which integrates understanding, skills and attitudes (Regulations Regarding the State Standard in Basic Education, the Subjects of Study Standards in Basic Education and Model Basic Educational Programmes, 2018).

However, question remains, what education policy will improve quality of education, because even the robust research results, using randomized controlled trials still tells us only half of the story. The research results are talking about what has worked in the particular time, place and certain population together with support factors which were in place in that particular place in time, that's why the context of the education policy is of such importance (Cartwright \& Hardie, 2012). Especially in time of vast different political initiatives, it is important to introduce in school data driven decision making to evaluate effectiveness of every initiative in specific context, because research shows that even feedback to student can in fact reduce the student achievement (Kluger \& DeNisi, 1996).

In the research literature through the randomized and quasiexperimental designs is growing promising evidence that using data can lead to the improvements of student achievements (Campbell \& Levin, 2009). Data decision making has become important theme linked to school accountability, improvement and educational policy (Mandinach \& Jackson, 2012). Two significant changes, which facilitates data use, have occurred. Firstly, the shift on the paradigm of assessment from summative to formative, with the goal to directly use information in improving instruction. Secondly, various technological solutions to manage vast amount of data (Lipton \& Wellman, 2012).

School teams, which attempt to use data in a meaningful way, often face several problems during their work with data, both on the individual level (for example, personal and social) and as whole group (for example, technical tools, sharing the same goal and group interdependency). It is a big mindset change for teacher, when workplace association moves from classroom to school. Structural change doesn't ensure cultural change, that's why simply providing time to the group meeting, doesn't increase teacher learning (Lipton \& Wellman, 2012). 
Everyday teachers and school principals are making decisions, which directly or indirectly impact student learning. The view that teachers and principals do not need data, because good decisions are based on experience are prevailed (Schildkamp, Lai, \& Earl, 2013). However, there is growing evidence that effective data use strategy improves student achievement. But use of data requires understanding what kind of data is needed and how it will be used (Datnow et al., 2007).

A key reason why data can lead to the improvements is the opportunity to monitor if students are reaching their goal and plan intervention on the fly. Second reason for using data is finding the most effective and cost-effective pollicises and practices in certain context, which improves student achievement. It is very similar idea about knowing the impact from the teacher perspective, which is relevant not only for the individual teacher, but also to the school as an organization (Hattie, 2012).

Unfortunately the question of "what work" in education can hardly be answered, most often it is very dependable of situation and circumstances (Macpherson \& Hendrick, 2019). Therefore, organisation's learning capability and seeking for the most effective solutions will be the only sustainable competitive advantage in the future. It is difficult to image that if teachers are not continuous learners and effective collaborators, they will be able to develop such qualities in students (DuFour, 1997; Kools \& Stoll, 2016).

\section{General Data Driven Decision framework}

Data driven decision making in education typically refers to teachers, principals, and administrators systematically collecting and analysing data to guide a range of decisions to help improve the success of students and schools (Schildkamp u.c., 2013). A use of data has become a strong part of educational policy in the school, district and national level. Researchers have been developed various theoretical frameworks for data-driven decision making (Abbott, 2008; Hamilton et al., 2009; Ikemoto \& Marsh, 2007a; Mandinach et al., 2008; Means et al., 2010; Schildkamp et al., 2013).

According to the Schildkamp the process of using data is like the linear process: starting from the purpose and then proceeding to data collection, analysis, interpretation and action. Howt the same time Schildkamp points out that there are some iterations and connections between the data collection, analysis and interpretations (Schildkamp et al., 2013).

Ikemoto and Marsh argues that making data-driven decision simple and straightforward process, we are failing to acknowledge how educators make meaning of the data (Ikemoto \& Marsh, 2007b). There are evidence, 
that models which are implemented, differ from straightforward and linear process. The variations are so great, that on one extreme for every problem is introduced the same solution (for example, allocating additional instructional time) to the models which really are capable of finding causality (Ikemoto \& Marsh, 2007b). According to the Ikemoto and Marsh there are at least four types of data-driven decision making: basic, analysis-focused, data focused, and inquiry focused. Data complexity depends on time, type and level of details, while analysis complexity varies for according to the technical analysis, iterations and expertise (Fig. 1). Distinction is important to understand that under the word "data driven based decision making" has been understood very different practices. Although there is no clear prioritising complex versus basic data or analysis, because the purpose of collecting and using data can be very different. According to Copland (2003), inquiry based analysis is of favour, because it is not only a way for solving problem, but also a way of an organization learning and capacity building (Copland, 2003).

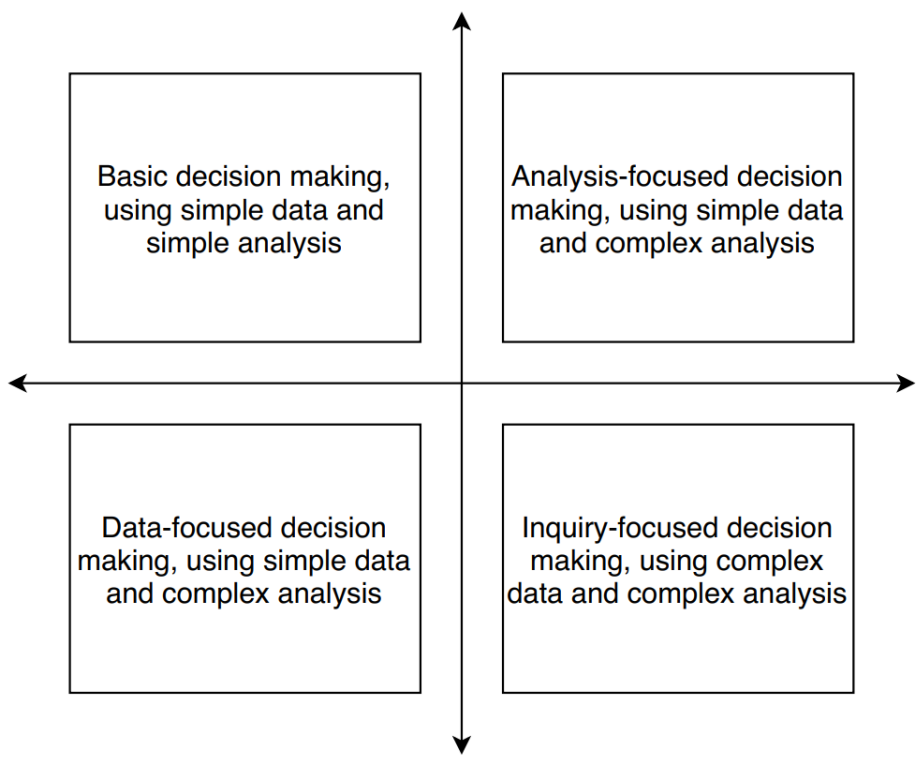

Figure 1. Four types of decision making, using different types of data and implementing different types of analysis. From "Cutting Through the "DataDriven" Mantra: Different Conceptions of Data-Driven Decision Making," by G. S. Ikemoto and J. a. Marsch, 2007, Yearbook of the National Society for the study of Education, 106. Copyright 2007 by the Blackwell Publishing. Adapted with permission. Yearbook of the National Society for the study of Education by National Society for the Study of Education Reproduced with permission of Blackwell Publishing in the format Republish in a journal/ magazine via Copyright Clearance Center 
In the article "A Perfect Time for Data Use: Using Data-Driven Decision Making to Inform Practice," Ellen B. Mandinach (2012) describes a conceptual framework for data-driven decision making and claims that, despite of growth of theoretical frameworks in literature, they consist of similar components: data, information and knowledge. However, in her presented framework, data driven decision making components are supplemented with cognitive skills which are needed to transform data. In order to transform raw data to knowledge, six relevant skills are outlined and embedded in conceptual framework: collecting and organising data, analysing and summarising information, synthesising and prioritising knowledge. The presented framework is not linear, but is based on the iterative process, where in the last phase the intended impact of intervention or proposed solution has been measured, which most likely leads to next steps of collecting another types of data and different analysis strategies (Mandinach, 2012).

In all general data-driven decision making frameworks, the question remains what type of data is available to teachers or school, how should it be organized in actionable way, not to be the burden, but be of use to instructional decisions or improvement planning in the level of school (Mandinach, 2012).

\section{Development of the Specific Data Driven Decision-making Framework for School Improvement}

Student educational achievements as a separate piece of information is of no use, because mostly people want to know whether the results are good or not good, and if not good whom to blame, and how to fix whatever is broken. For that we need not only student learning outcomes data, but additional educational, policy and non-educational data, because the impact of these context and non-educational factors can be huge. When school performance is good, the reason is most likely both - quality of education and non-educational factors influence. And it is not easy to understand and figure out which is influence more, but it is very important to include such factors in the framework (Koretz, 2008, 2017).

According to the research the first and most important factor is teacher quality, although there are some critics for the research methodology, the conclusions about teacher quality as a main factors has been proved over and over worldwide (Hanushek, 2011; Wiliam, 2018b). The second most important factor is leadership, which have been studied extensively and the research is clear, that primarily talented leadership serves as a catalyst for developing the potential of the organization. Leadership effect is second 
only to the teacher quality (Day, Gu, \& Sammons, 2016; Hallinger, 2014; Hallinger \& Heck, 1998; Leithwood, Harris, \& Hopkins, 2008).

In previous research authors have developed framework to report assessment data on actionable scale for school and teacher (Table 1). For the identification of the level of complexity of item Structure of Observed Learning Outcomes (SOLO) taxonomy has been used (Biggs \& Collis, 1982; Pestovs, Namsone, Čakāne, \& Saleniece, 2019). Authors have modified the original SOLO taxonomy, additionally dividing the second level of complexity. The II level of complexity has been divided into two groups by varying item context. When the context is familiar to the student, the item has been mapped as IIA level and unfamiliar new context has been mapped as IIB. Average student performance in classroom and school level has been calculated and compared with national level.

Table 1. Student achievement reporting framework in Mathematics, Science and Native language (Latvian language) according to the subcomponents and SOLO level of complexity

\begin{tabular}{|c|c|c|c|c|c|c|}
\hline \multirow[t]{2}{*}{ Subject } & \multirow{2}{*}{ Subject subcomponents } & \multicolumn{5}{|c|}{ SOLO level of complexity } \\
\hline & & I & IIA & IIB & III & IV \\
\hline \multirow[t]{4}{*}{ Mathematics } & Model/formulate & & & & & \\
\hline & Transform/manipulate & & & & & \\
\hline & Infare/draw conclusions & & & & & \\
\hline & Communicate & & & & & \\
\hline \multirow[t]{3}{*}{ Scientific } & Explain phenomena scientifically & & & & & \\
\hline & $\begin{array}{l}\text { Interpret data and evidence } \\
\text { scientifically }\end{array}$ & & & & & \\
\hline & Evaluate and design scientific enquiry & & & & & \\
\hline \multirow[t]{4}{*}{ Language } & Language conventions & & & & & \\
\hline & Retrieve explicitly stated information & & & & & \\
\hline & $\begin{array}{l}\text { Interpret and integrate ideas and } \\
\text { information }\end{array}$ & & & & & \\
\hline & Communicate & & & & & \\
\hline
\end{tabular}

\section{Aim of the Study}

The aim of the study is the development of the initial framework for making data-driven decisions and piloting the framework at school level, using one, the most important key factor - teacher instructional quality and 6th grade national level large-scale assessment data in Science, Native Language (Latvian language) and Math as a student achievement indicator. 


\section{Materials and Methods}

Authors reviewed several general data-driven decision theoretical frameworks, adapted theoretical framework of the key factors, which influences the student learning outcomes and present an effective way of collecting, and organizing data, analysing and summarizing information and synthesizing and prioritizing knowledge to decide and develop action plan for school improvement. In the developed theoretical framework, key educational factors are included, including students' background data and characteristics (Fig. 2).

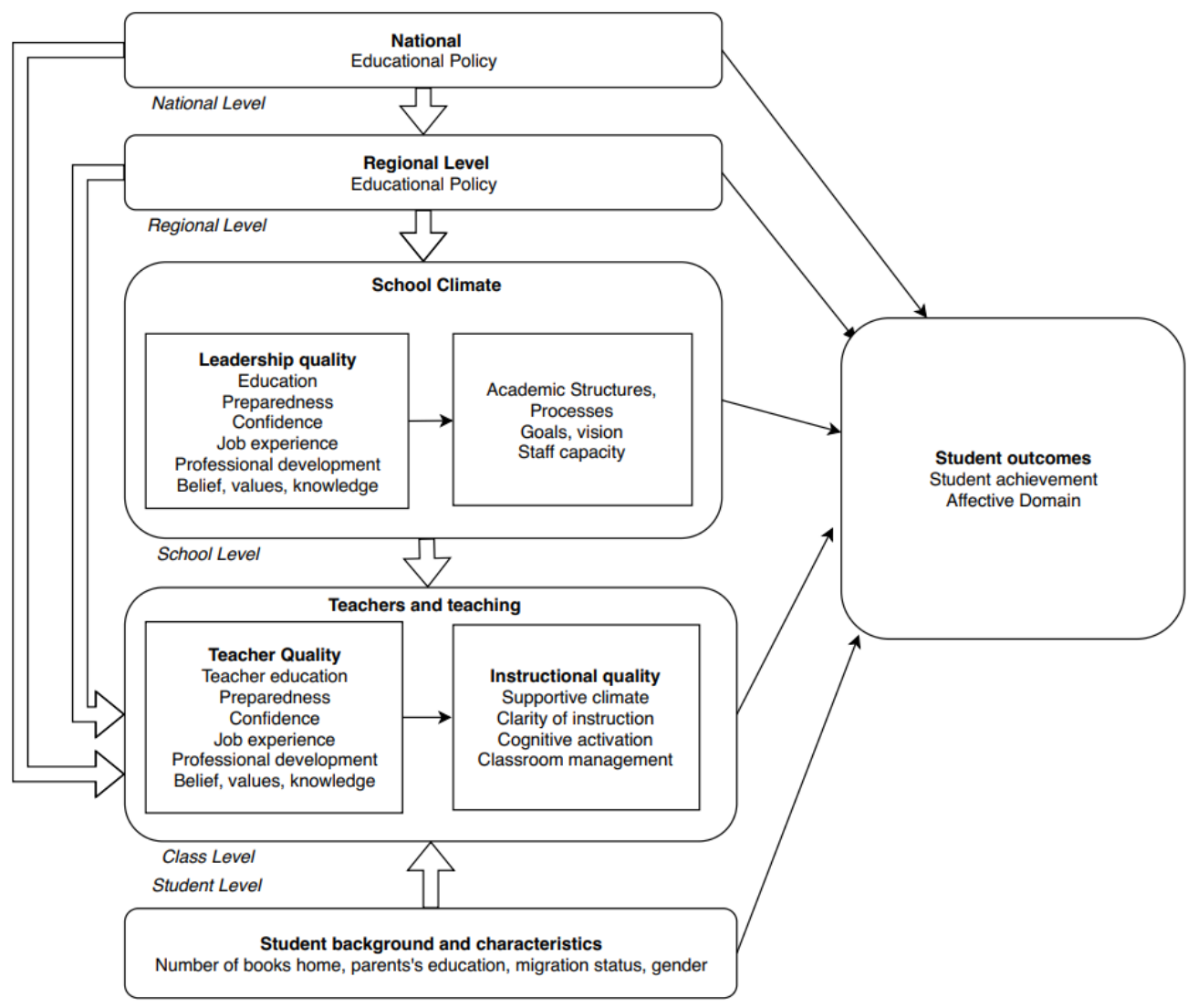

Figure 2. Conceptual framework of main factors of student learning outcomes. From "Teacher Quality, Instructional Quality and Student Outcomes:

Relationships Across Countries, Cohorts and Time. IEA Research for Education. Volume 2.," by T. Nilsen \& J. E. Gustafsson, 2016, International Association for the Evaluation of Educational Achievement. Copyright 2016 by the International Association for the Evaluation of Educational Achievement (IEA). Adapted with changes under the terms of the Creative Commons Attribution NonCommercial 4.0 International License (http://creativecommons.org/licenses/by-nc/4.0/) 
1. According to the previously developed framework, authors identify assessment indicators in the national level large-scale assessments in the $6^{\text {th }}$ grade in Science, Native language (Latvian language) and Mathematics of the Year 2019. Assessment indicators are mapped according to the framework subcomponents and according to the SOLO level of complexity of item. Average achievement results in the classroom and at national level have been calculated, using classical test theory in R 3.6.0. and Microsoft Excel 365 environment.

2. In order to gather data of the instructional quality, a previously developed framework has been used to observe teacher performance in classroom. Designed and piloted teacher performance assessment framework for teaching $21^{\text {st }}$ century skills, includes 8 categories and 13 criteria. According to the theoretical framework, performance level descriptions have been created and validated in the school practice, to assess the performance of teachers. Performance has been described in four levels: from the 0 (not observed) to the 4 (expert performance) (Bertule, Dudareva, Namsone, Cakane, \& Butkevica, 2019). In this study three categories and nine criteria have been used during the lesson observation (Table 2). The teacher performance, who are teaching in the $6^{\text {th }}$ grade have been analysed in depth, but for school leadership average observed teacher performance in school has been provided in addition.

Table 2. Teacher performance assessment categories and criteria to teach $21^{\text {st }}$ century skills (Bertule, Dudareva, Namsone, Čakāne, \& Butkēviča, 2019)

\begin{tabular}{|l|l|l|l|l|l|l|}
\hline \multirow{2}{*}{ Category } & \multicolumn{5}{|c|}{ Criteria } & \multicolumn{5}{c|}{$\begin{array}{c}\text { Levels of } \\
\text { performance }\end{array}$} \\
\cline { 3 - 7 } & & $\mathbf{0}$ & $\mathbf{1}$ & $\mathbf{2}$ & $\mathbf{3}$ & $\mathbf{4}$ \\
\hline Cognitive activization & 2.1 Learning task for cognitive depth & & & & & \\
\hline & 2.2 Classroom discourse & & & & & \\
\hline $\begin{array}{l}\text { Classroom } \\
\text { management and } \\
\text { clarity of instruction }\end{array}$ & 5.1 Lesson design & & & & & \\
\hline & & & & & & \\
\hline & 5.2 Teaching techniques & & & & & \\
\hline Student support & 6.1 Curriculum & & & & & \\
\hline & 1.1 Learning goals & & & & & \\
\hline & 1.2 Metacognitive skills & & & & & \\
\hline & 5.3 Differentiation, personalization & & & & & \\
\hline & 6.2 Feedback & & & & & \\
\hline
\end{tabular}


3. In the research participated two municipalities (seven and eight schools in each municipality). In this paper data from one school (three classes) are studied as case study, in order to begin the piloting of developed model. Authors together with leadership team, identified specific patterns according to the school data, which included average achievement data in the $6^{\text {th }}$ grade in Science, Native language (Latvian language) and Mathematics of the Year 2019 and performance of teachers' group (number of teachers $=6$ ).

\section{Results}

In the case study, student achievement average data are presented for every $6^{\text {th }}$ grade class (three in total) in one municipality school, according to the Table 1 framework. The total student population in municipality is approximately 700 students.

Table 3. Student achievement average data and difference from national level average according to subjects and level of complexity. Municipality School. Grade 6.1

\begin{tabular}{|c|c|c|c|c|c|c|c|c|c|}
\hline \multirow[t]{2}{*}{ Subject } & \multirow[t]{2}{*}{$\begin{array}{l}\text { Subject sub- } \\
\text { components }\end{array}$} & \multicolumn{8}{|c|}{$\begin{array}{c}\text { Average student achievement and the difference } \\
\text { with national level student achievement across } \\
\text { the country }\end{array}$} \\
\hline & & I & & IIA & & IIB & & III & \\
\hline & & $\%$ & & $\%$ & & $\%$ & & $\%$ & \\
\hline Mathematics & $\begin{array}{l}\text { Transform / } \\
\text { manipulate }\end{array}$ & 63.1 & -14.3 & 72.7 & -2.4 & 28.4 & -15.2 & 35.5 & -5.3 \\
\hline \multirow{3}{*}{ Science } & $\begin{array}{l}\text { Explain } \\
\text { phenomena } \\
\text { scientifically }\end{array}$ & 73.7 & -2.2 & 57.9 & -9.3 & 27.6 & -22.3 & 21.1 & -17.9 \\
\hline & $\begin{array}{l}\text { Evaluate and } \\
\text { design scientific } \\
\text { enquiry }\end{array}$ & 94.7 & 14.5 & na & na & 39.5 & -14.2 & na & na \\
\hline & $\begin{array}{l}\text { Interpret data } \\
\text { and evidence } \\
\text { scientifically }\end{array}$ & na & na & 68.4 & -5.7 & 68.4 & 12.1 & 39.5 & 1.4 \\
\hline \multirow{2}{*}{$\begin{array}{l}\text { Latvian } \\
\text { Language }\end{array}$} & \begin{tabular}{|l|l}
$\begin{array}{l}\text { Language } \\
\text { conventions }\end{array}$ \\
\end{tabular} & 58.2 & -9.5 & 40.9 & -28.6 & 20.3 & -22.0 & na & na \\
\hline & $\begin{array}{l}\text { Interpret and } \\
\text { integrate ideas } \\
\text { and information }\end{array}$ & 70.7 & -1.3 & 83.0 & 16.0 & 59.1 & 3.5 & 13.6 & -18.9 \\
\hline
\end{tabular}


Table 4. Student achievement average data and difference from national level average according to subjects and level of complexity. Municipality School. Grade 6.2

\begin{tabular}{|c|c|c|c|c|c|c|c|c|c|}
\hline \multirow[t]{2}{*}{ Subject } & \multirow[t]{2}{*}{$\begin{array}{c}\text { Subject } \\
\text { subcomponents }\end{array}$} & \multicolumn{8}{|c|}{$\begin{array}{c}\text { Average student achievement and the difference } \\
\text { with national level student achievement across } \\
\text { the country }\end{array}$} \\
\hline & & I & & IIA & & IIB & & III & \\
\hline & & $\%$ & & $\%$ & & $\%$ & & $\%$ & \\
\hline Mathematics & $\begin{array}{l}\text { Transform / } \\
\text { manipulate }\end{array}$ & 52.5 & -24.9 & 67.0 & -8.1 & 29.4 & -14.2 & 29.0 & -11.7 \\
\hline \multirow{3}{*}{ Science } & $\begin{array}{l}\text { Explain } \\
\text { phenomena } \\
\text { scientifically }\end{array}$ & 60.8 & -15.1 & 52.5 & -14.7 & 31.3 & -18.7 & 27.5 & -11.5 \\
\hline & $\begin{array}{l}\text { Evaluate and } \\
\text { design scientific } \\
\text { enquiry }\end{array}$ & 85.0 & 4.8 & na & na & 35.0 & -18.7 & na & na \\
\hline & $\begin{array}{l}\text { Interpret data } \\
\text { and evidence } \\
\text { scientifically }\end{array}$ & na & na & 60.0 & -14.1 & 35.0 & -21.4 & 30.0 & -8.1 \\
\hline \multirow{2}{*}{$\begin{array}{l}\text { Latvian } \\
\text { Language }\end{array}$} & \begin{tabular}{|l|l}
$\begin{array}{l}\text { Language } \\
\text { conventions }\end{array}$ \\
\end{tabular} & 60.9 & -6.8 & 46.7 & -22.8 & 42.3 & 0.1 & na & na \\
\hline & $\begin{array}{l}\text { Interpret and } \\
\text { integrate ideas } \\
\text { and information }\end{array}$ & 66.0 & -6.1 & 80.4 & 13.5 & 54.9 & -0.6 & 23.9 & -8.7 \\
\hline
\end{tabular}

Table 5. Student achievement average data and difference from national level average according to subjects and level of complexity. Municipality School. Grade 6.3

\begin{tabular}{|c|c|c|c|c|c|c|c|c|c|}
\hline \multirow[t]{2}{*}{ Subject } & \multirow[t]{2}{*}{$\begin{array}{c}\text { Subject } \\
\text { subcomponents }\end{array}$} & \multicolumn{8}{|c|}{$\begin{array}{l}\text { Average student achievement and the difference } \\
\text { with national level student achievement across } \\
\text { the country }\end{array}$} \\
\hline & & I & & IIA & & IIB & & III & \\
\hline & & $\%$ & & $\%$ & & $\%$ & & $\%$ & \\
\hline Mathematics & $\begin{array}{l}\text { Transform / } \\
\text { manipulate }\end{array}$ & 64.7 & -12.7 & 69.4 & -5.7 & 30.9 & -12.7 & 24.7 & -16.0 \\
\hline \multirow{3}{*}{ Science } & $\begin{array}{l}\text { Explain phenomena } \\
\text { scientifically }\end{array}$ & 72.8 & -3.1 & 63.2 & -4.0 & 26.3 & -23.6 & 26.3 & -12.6 \\
\hline & $\begin{array}{l}\text { Evaluate and design } \\
\text { scientific enquiry }\end{array}$ & 79.0 & -1.3 & na & na & 31.6 & -22.1 & na & na \\
\hline & $\begin{array}{l}\text { Interpret data } \\
\text { and evidence } \\
\text { scientifically }\end{array}$ & na & na & 63.2 & -10.9 & 36.8 & -19.5 & 29.0 & -9.1 \\
\hline \multirow{2}{*}{$\begin{array}{l}\text { Latvian } \\
\text { Language }\end{array}$} & $\begin{array}{l}\text { Language } \\
\text { conventions }\end{array}$ & 59.0 & -8.7 & 63.2 & -6.4 & 49.3 & 7.1 & na & na \\
\hline & $\begin{array}{l}\text { Interpret and } \\
\text { integrate ideas and } \\
\text { information }\end{array}$ & 65.1 & -7.0 & 82.9 & 15.9 & 62.2 & 6.6 & 50.0 & 17.4 \\
\hline
\end{tabular}


During the analysis of the national level large scale assessments of Year 2019, the authors couldn't identify assessment items in several subject subcomponents and items, which assessed SOLO IV level of complexity. The minus symbol represents, that the average achievement level of the class is below the national achievement level.

Table 6. Science, Mathematics and Native language (Latvian language) $6^{\text {th }}$ grade teacher performance level. Municipality School. Grades are indicated

\begin{tabular}{|c|c|c|c|c|c|c|c|c|c|c|}
\hline \multirow[t]{2}{*}{$\begin{array}{l}\text { Teacher } \\
\text { Code }\end{array}$} & \multirow[t]{2}{*}{ Subject/ grade } & \multicolumn{4}{|c|}{ Student support } & \multicolumn{2}{|c|}{$\begin{array}{l}\text { Cognitive } \\
\text { activization }\end{array}$} & \multicolumn{3}{|c|}{$\begin{array}{c}\text { Classroom } \\
\text { management } \\
\text { and clarity of } \\
\text { instruction }\end{array}$} \\
\hline & & 1.1 . & 1.2. & 5.3 . & 6.2 . & 2.1 . & 2.2. & 5.1 . & 5.2 . & 6.1 . \\
\hline 114 & Native language / 6.2, 6.3 & 1 & 0 & 0 & 1 & 1 & 1 & 0 & 1 & 1 \\
\hline 115 & Science / 6.1, 6.2, 6.3 & 0 & 0 & 0 & 1 & 0 & 1 & 2 & 1 & 1 \\
\hline 116 & Native language / 6.1 & 1 & 0 & 0 & 0 & 1 & 1 & 1 & 1 & 2 \\
\hline 118 & Mathematics / 6.1 & 1 & 0 & 0 & 1 & 0 & 1 & 2 & 1 & 1 \\
\hline 120 & Mathematics / 6.3 & 3 & 2 & 2 & 2 & 3 & 3 & 3 & 3 & 3 \\
\hline 122 & Mathematics / 6.2 & 1 & 0 & 1 & 1 & 0 & 1 & 2 & 3 & 2 \\
\hline
\end{tabular}

Average performance of the teachers in the school is presented according to the three categories and eight criteria (Fig. 3). The categories and criteria are the same, as discussed in the theoretical framework (Table 2). The maximum scale of the presented diagram is 4 , as has been described the level of an expert. Acceptable level of performance is 3, where teacher performance, according to the framework has been described as proficient.

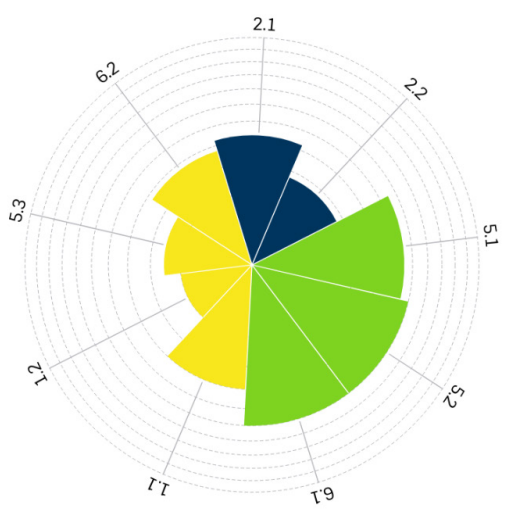

$\checkmark$ VIZZLOO

Figure 3. Average performance of observed teachers (number $=6$ ) according to the three categories and eight criteria for the developing $21^{\text {st }}$ century skills 
Authors point out that for this teacher group strength is the category of classroom management and clarity of instruction, which includes lesson design, teaching techniques and curriculum, which is suitable to the student. The performance on three criteria in other two categories is insufficient: classroom discourse, differentiating and student metacognitive skill development.

Development of the school action plan most likely are based on the criteria, where has been observed as most problematic. Firstly, insufficient Science teacher performance (dominating Level 0 and Level 1) has been identified in category of classroom management and clarity of instruction during study. Average class achievement compared to national average also signalizes the problem. In such case personalized feedback is needed, to improve lesson design, teaching techniques and implemented curriculum. For Mathematics and Native language (Latvian language) teacher professional development mostly is associated with cognitive activization, more productive task development and classroom discourse improvement.

\section{Conclusions}

As every study, this study also has a limitation. Authors point out that, there have been not identified assessment items in all subject subcategories and different SOLO levels of complexity. Some subject subcomponents consist of only several assessment items, which lowers the reliability of results.

Most schools are data rich, but the challenge remains in selecting and analysing the right data to transform it to knowledge. Most often student assessment data has been integrated in the data driven decision making, but these kinds of data don't point out the solutions, often it is only signalizing the problem.

Authors during the research have piloted an initially developed model in which general steps of data driven decision making have been linked to the theoretical framework, where key factors, which influence student achievement have been identified and teacher instructional performance quality has been assessed in this study, with the previously developed teacher performance assessment instruments. Using the developed model, it is possible to identify the weaknesses and strengths of the observed teacher group.

For further research it is necessary to empirically validate the initially developed model. Develop and empirically validate assessment instruments for the key factors (leadership practices, student background and characteristics, national and municipality level policy), which are 
influencing student outcomes and evaluate and measure the impact and effectiveness of developed action plan for the school improvement.

This research is supported by the research project "Innovative approaches to evaluate school quality for competence development".

\section{References}

Abbott, D. V. (2008). A functionality framework for educational organizations: Achieving accountability at scale. Data driven school improvement: Linking data and learning, 257-276.

Bertule, D., Dudareva, I., Namsone, D., Cakane, L., \& Butkevica, A. (2019, martā). FRAMEWORK OF TEACHER PERFORMANCE ASSESSMENT TO SUPPORT TEACHING $21^{\text {ST }}$ CENTURY SKILLS. 5742-5752. https://doi.org/10.21125/inted.2019.1410.

Bertule, D., Dudareva, I., Namsone, D., Čakāne, L., \& Butkēviča, A. (2019). Framework of Teacher Performance Assessment to Support Teaching $21^{\text {st }}$ Century Skills. Submitted for Proceedings for INTED. Iesniegts $13^{\text {th }}$ annual International Technology, Education and Development (INTED) Conference, Valencia.

Biggs, J. B., \& Collis, K. F. (1982). Evaluating the quality of learning: The SOLO taxonomy (structure of the observed learning outcome). New York: Academic Press.

Campbell, C., \& Levin, B. (2009). Using data to support educational improvement. Educational Assessment, Evaluation and Accountability, 21(1), 47-65. https://doi. org/10.1007/s11092-008-9063-x.

Cartwright, N., \& Hardie, J. (2012). Evidence-based policy: A practical guide to doing it better. Oxford; New York: Oxford University Press.

Copland, M. A. (2003). Leadership of Inquiry: Building and Sustaining Capacity for School Improvement. Educational Evaluation and Policy Analysis, 25(4), 375-395. https:// doi.org/10.3102/01623737025004375.

Day, C., Gu, Q., \& Sammons, P. (2016). The impact of leadership on student outcomes: How successful school leaders use transformational and instructional strategies to make a difference. Educational Administration Quarterly, 52(2), 221-258.

Datnow, A., Park, V., \& Wohlstetter, P. (2007). Achieving with data: How high-performing school systems use data to improve instruction for elementary students. Center of Educational Governance. Rossier School of Education. University of ....

Dorn, D. (2009). This job is" getting old": Measuring changes in job opportunities using occupational age structure. American Economic Review, 99(2), 45-51.

DuFour, R. P. (1997). The school as a learning organization: Recommendations for school improvement. NASSP bulletin, 81(588), 81-87.

Hallinger, P. (2011). Leadership for learning: Lessons from 40 years of empirical research. Journal of Educational Administration, 49(2), 125-142. https://doi. org/10.1108/09578231111116699.

Hallinger, P. (2014). Reviewing Reviews of Research in Educational Leadership: An Empirical Assessment. Educational Administration Quarterly, 50(4), 539-576. https://doi. org/10.1177/0013161X13506594.

Hallinger, P., \& Heck, R. H. (1998). Exploring the Principal's Contribution to School Effectiveness: 1980-1995. School Effectiveness and School Improvement, 9(2), 157-191. https://doi.org/10.1080/0924345980090203. 
Hamilton, L., Halverson, R., Jackson, S. S., Mandinach, E., Supovitz, J. A., \& Wayman, J. C. (2009). Using Student Achievement Data to Support Instructional Decision Making. IES Practice Guide. NCEE 2009-4067. National Center for Education Evaluation and Regional Assistance.

Hanushek, E. A. (2011). The economic value of higher teacher quality. Economics of Education review, 30(3), 466-479.

Hattie, J. (2012). Visible learning for teachers: Maximizing impact on learning. London; New York: Routledge.

Ikemoto, G. S., \& Marsh, J. a. (2007a). chapter 5 Cutting Through the "DataDriven" Mantra: Different Conceptions of Data-Driven Decision Making. Yearbook of the National Society for the Study of Education, 106(1), 105-131. https://doi. org/10.1111/j.1744-7984.2007.00099.x.

Ikemoto, G. S., \& Marsh, J. a. (2007b). chapter 5 Cutting Through the "DataDriven" Mantra: Different Conceptions of Data-Driven Decision Making. Yearbook of the National Society for the Study of Education, 106(1), 105-131. https://doi. org/10.1111/j.1744-7984.2007.00099.x.

Kluger, A. N., \& DeNisi, A. (1996). The effects of feedback interventions on performance: A historical review, a meta-analysis, and a preliminary feedback intervention theory. Psychological bulletin, 119(2), 254.

Kools, M., \& Stoll, L. (2016). What makes a school a learning organisation?

Koretz, D. M. (2008). Measuring up: What educational testing really tells us. Cambridge, Mass: Harvard University Press.

Koretz, D. M. (2017). The testing charade: Pretending to make schools better. Chicago; London: The University of Chicago Press.

Leithwood, K., Harris, A., \& Hopkins, D. (2008). Seven strong claims about successful school leadership. School leadership and management, 28(1), 27-42.

Lipton, L., \& Wellman, B. M. (2012). Got data? now what? creating and leading cultures of inquiry. Bloomington, IN: Solution Tree Press.

Macpherson, R., \& Hendrick, C. (2019). What Does This Look Like in the Classroom?: Bridging the Gap Between Research and Practice. Iegūts no https://books.google.lv/ books?id $=$ tFSdwwEACAAJ.

Mandinach, E. B., Honey, M., Light, D., \& Brunner, C. (2008). A conceptual framework for data-driven decision making. Data-driven school improvement: Linking data and learning, 13-31.

Mandinach, Ellen B. (2012). A Perfect Time for Data Use: Using Data-Driven Decision Making to Inform Practice. Educational Psychologist, 47(2), 71-85. https://doi.org/10.10 80/00461520.2012.667064.

Mandinach, Ellen Beth, \& Jackson, S. S. (2012). Transforming teaching and learning through data-driven decision making. Thousand Oaks: Corwin Press.

Means, B., Padilla, C., \& Gallagher, L. (2010). Use of Education Data at the Local Level: From Accountability to Instructional Improvement. US Department of Education.

Nilsen, T., \& Gustafsson, J. E. (2016). Teacher Quality, Instructional Quality and Student Outcomes: Relationships across Countries, Cohorts and Time. IEA Research for Education. Volume 2. International Association for the Evaluation of Educational Achievement. Herengracht 487, Amsterdam, 1017 BT, The Netherlands. 
Pestovs, P., Namsone, D., Čakāne, L., \& Saleniece, I. (2019). ALIGNMENT OF 6TH GRADE LARGE-SCALE ASSESSMENT CONSTRUCTS WITH THE REVISED CURRICULUM FRAMEWORK. SOCIETY. INTEGRATION. EDUCATION. Proceedings of the International Scientific Conference, 2, 387. https://doi.org/10.17770/sie2019vol2.3811.

Regulations Regarding the State Standard in Basic Education, the Subjects of Study Standards in Basic Education and Model Basic Educational Programmes, 747, (2018). Retrieved from https://likumi.lv/ta/id/303768.

Schildkamp, K., Lai, M. K., \& Earl, L. M. (Red.). (2013). Data-based decision making in education: Challenges and opportunities. Dordrecht ; London ; New York: Springer.

Wiliam, D. (2018a). Creating the schools our children need: Why what we're doing now won't help much (and what we can do instead). West Palm Beach, Florida: Learning Sciences International.

Wiliam, D. (2018b). Creating the schools our children need: Why what we're doing now won't help much (and what we can do instead). West Palm Beach, Florida: Learning Sciences International. 